\title{
Research on Cutting-Temperature Field and Distribution of Heat Rates among a Workpiece, Cutter, and Chip for High-Speed Cutting Based on Analytical and Numerical Methods
}

\author{
H. P. An, ${ }^{a, 1}$ Z. Y. Rui, ${ }^{b, 2}$ R. F. Wang, ${ }^{c, 3}$ and Z. M. Zhang ${ }^{c, 4}$ \\ ${ }^{a}$ Institute for Mechanic Inspection and Fault Diagnosis, Lanzhou City University, Lanzhou, China \\ ${ }^{\mathrm{b}}$ College of Mechano-Electronic Engineering, Lanzhou University of Technology, Lanzhou, China \\ ${ }^{c}$ Lanzhou Jiao tong University, Lanzhou, China \\ 1 ahp2004@126.com \\ 2 Zhiy_rui@163.com \\ 3 Wangruifeng0808@163.com \\ 4Zhangzhimei65@126.com
}

УДК 539.4

\section{Исследование поля температур резания и распределения удельного расхода тепла между заготовкой, резаком и стружкой при высокоскоростном резании на основе аналитических и численных методов}

\author{
Х. П. $\mathbf{A н}^{\mathrm{a}}$, Дж. Ю. Руи ${ }^{\sigma}$, Р. Ф. Ванг ${ }^{\mathrm{B}}$, Дж. М. Джанг ${ }^{\mathrm{B}}$

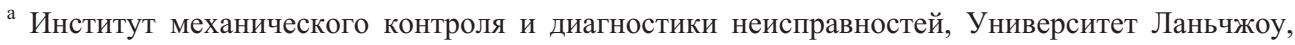 \\ Ланьчжоу, Китай \\ ${ }^{6}$ Факультет механической и электронной техники, Университет Ланьчжоу, Ланьчжоу, Китай \\ в Университет Ланьчжоу Жао тонга, Ланьчжоу, Китай
}

\begin{abstract}
Высокоскоростное резание широко используется в авиакосмической, автомобильной и других отраслях промышленности. Однако комплексный механизм процесса высокоскоростного резания ещче недостаточно изучен. На основе анализа теплового равновесия между тепловыделением и потреблением энергии при высокоскоростной обработке без смазочно-охлаждающей жидкости предложены модели тепловых источников и полей температур резания. Для анализа влияния выделения и выхода тепла при обработке на высоких скоростях резания выведены математические модели температур резания для трех зон деформирования. Определены соотношения распределения тепла между стружкой, резаком и заготовкой, иллюстрирующие степень пропорциональности со скоростью с помощью пакета прикладньх программ MATLAB.
\end{abstract}

Ключевые слова: высокоскоростное резание без смазочно-охлаждающей жидкости, поле температур, распределение тепла, выделяющегося при резании, аналитический метод.

Introduction. Cutting heat is a kind of important physical phenomenon during the metal-cutting process, which implies a temperature increment in the cutting area. This temperature and its distribution can affect the cutting forces, chip deformation, tool wear, and finished surface quality. For the particular cutting conditions, the temperature depends on cutting speed. The major part of energy spent during high-speed cutting (HSC) is converted into heat energy, with a small share being stored in the deformed materials [1-3]. 
Friction power dissipation almost fully turns into a heat energy and enhance the temperature rise. However, the effect of HSC is different from that of general cutting. As compared to general cutting, HSC has a lower temperature and smaller cutting forces $[4,5]$. Thus, it is very important for comprehension of the tool wear mechanism to study the temperature field and distribution rates of heat transferred to a workpiece, cutter and chip under dry-cutting conditions. In general, the temperature field can be obtained by experimental methods, numerical simulation, and mathematical analysis. Experimental methods can provide the approximate temperature values by surveying specific points on tool or/and workpiece in course of machining, but this would require much time and cost. Numerical simulation is useful to solve nonlinear heat conduction problems or partial differential equations for objects having complicated shapes and boundary conditions $[6$, 7]. The machining course can be imitated by the use of some simulation software, while some appropriate mathematical models and cutting tests are required to estimate the errors. Mathematical analysis is applied to deal with linear problems or few nonlinear heat conduction objects of simple geometry, but the veracity of the results obtained is hard to be estimated. The heat source method is a way to solve various heat conduction problems via some temperature formulas using an integral method for a dotted heat source located in an imaginary infinite heat conductor plane, which can yield a simple and approximately correct answer. We propose a heat conduction model by the analysis of laws of heat generation and spreading from cutting pattern, in which the average temperature of the cutting area can be obtained by combining the heat source method with an analytical technique. Moreover, some distributions rates $\left(R_{1}\right.$ and $\left.R_{3}\right)$ of cutting heat with cutting speed increment are calculated using the MATLAB software.

Heat Source and Model of Heat Conduction for Cutting. For energy dissipation to undergo elastic-plastic deformation and frictional work during metal cutting processes, the formed chips from plastic-deformation work consumed in the material shear slip are dominant, while frictional work values corresponding to domains between the rake face of cutter and the chip underside, as well as the back face of cutter and machined face, are relative low. The schematic diagram for the model of three cutting-heat sources is illustrated by Fig. 1.

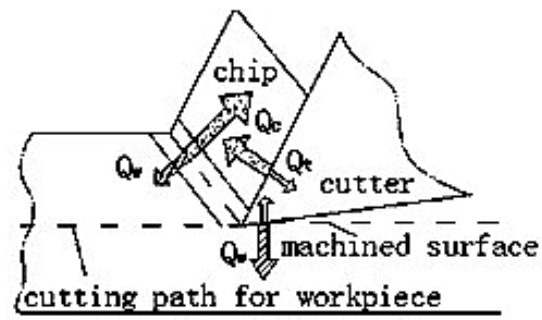

Fig. 1. Heat source of cutting and their models of heat conduction.

The total power consumption of HSC, containing the energy $\left(W_{n}\right)$ consumed in forming new surface of chip bottom and interface energy of work surface can be neglected, as compared to the total energy consumption, because it is very low. The deformation energy $\left(W_{s}\right)$ in the shear zone is large, and frictional work $\left(W_{f}\right)$ from rake face of cutter and bottom of chip, as well as the back surface of cutter and finished surface of workpiece, is smaller than $W_{s}$, while the wasted power $\left(W_{n}\right)$ is negligible due to instant change of shear slipping in the cutting material. Suppose that $A_{1}, A_{2}$, and $A_{3}$ are the areas of shear surface, cutter-chip contact, and cutter-workpiece contact, respectively. Accordingly, $q_{1}$, $q_{2}$, and $q_{3}$ represent the heat quantities produced for the three zones per unit time interval and unit area. Then, we have

$$
Q=q_{1} A_{1}+q_{2} A_{2}+q_{3} A_{3},
$$


where $Q$ represents the total energy produced per unit time and unit area, $q_{1}$ is a heat flux due to power dissipation of shear deformation, $q_{1}=F_{s} v_{s} /\left(A_{c} \csc \phi\right)=\tau_{s} v_{s}\left[\mathrm{~J} /\left(\mathrm{s} \cdot \mathrm{m}^{2}\right)\right]$, in which $\phi$ is shear angle $(\mathrm{deg}), F_{s}$ is shear force $(\mathrm{N}), v_{s}$ is shear slipping speed $(\mathrm{m} / \mathrm{s}), A_{c}$ is section area of cutting layer $\left(\mathrm{m}^{2}\right), A_{c}=a_{c} a_{w}, a_{c}$ is thickness of cutting layer $(\mathrm{m}), \tau_{s}$ is shear stress $(\mathrm{Pa}), q_{2}$ is heat flux transformed from frictional work between cutter and chip interface $\left[\mathrm{J} /\left(\mathrm{s} \cdot \mathrm{m}^{2}\right)\right], q_{2}=F_{f 1} v_{c} /\left(l_{f} a_{w}\right), F_{f 1}$ is frictional force $(\mathrm{N}), v_{c}$ is sliding speed of chip along the cutter rake face $(\mathrm{m} / \mathrm{s}), l_{f}$ is length of cutter-chip contact (m), $a_{w}$ is width of cutting layer $(\mathrm{m}), q_{3}$ is heat flux converted by frictional work between cutter and workpiece $\left[\mathrm{J} /\left(\mathrm{s} \cdot \mathrm{m}^{2}\right)\right], q_{3}=F_{f} v /\left(l_{w} a_{w}\right), F_{f}$ is frictional force between cutter and workpiece $(\mathrm{N}), v$ is cutting speed $(\mathrm{m} / \mathrm{s})$, and $l_{w}$ is length of contact between the back surface of cutter and workpiece $(\mathrm{m})$.

Factors affecting heat conduction are as follows.

1. Character of heat conduction of workpiece material. Higher the heat conductivity coefficient, higher the value of heat flowing into the workpiece and chip per unit time. Lower the temperature in cutting area, less the cutter wear, but cutting temperature rise leads to thermal deformation of the machined workpiece. Moreover, a high temperature in the cutting area results in oxidation - or/and diffusion of the cutter area.

2. Character of heat conduction of the tool material. A higher coefficient of heat conduction of tool material implies a higher heat energy spread into the tool per unit time, which results in a less temperature rise in the cutting area and less tool wear, and thus in prolongation of the tool life.

3. Impact of surrounding medium. An efficient coolant can take away a lot of cutting heat and slow down the tool wear process.

4. Time of tool-workpiece interaction. HSC makes chips splash quickly and remove a lot of cutting heat, which tends to lower temperature values in the cutting zone.

Field of Cutting Temperature. Field of cutting temperature is a distribution of temperature in the cutting zone. The temperature field of HSC consists of zone of shear deformation, frictional portion of rake face of tool to chip and tool-workpiece flank surface.

Average Temperature of Shear Plan. The cut layers in a workpiece turn into chips by shear deformation under squeezing action of a tool. The major part of energy consumed in shear deformation is transformed into the heat energy under the dry-cutting conditions, some part of which is conducted to chips and the part is transferred to the workpiece. Assume that $R_{1}$ is the share of heat transferred to a chip. Thus, per unit time interval, heat energy values corresponding to chips and workpieces are $R_{1} q_{1} a_{c} a_{w} / \sin \phi$ and $\left(1-R_{1}\right) q_{1} a_{c} a_{w} / \sin \phi$, respectively. Without regard of heat convection into air, the average temperature rise in the shear plane under the action of heat value $R_{1} q_{1} a_{c} a_{w} / \sin \phi$ can be expressed as

$$
\Delta T_{s}=\frac{R_{1} q_{1} a_{c} a_{w} / \sin \phi}{c_{1} \rho_{1} v a_{c} a_{w}}=\frac{R_{1} q_{1}}{c_{1} \rho_{1} v \sin \phi},
$$

where $\Delta T_{s}$ is the average temperature rise in the shear plane $\left({ }^{\circ} \mathrm{C}\right), c_{1}$ is specific heat for the average temperature of $\left(T_{0} \sim \bar{T}_{S}\right)$ in the workpiece material $\left[\mathrm{J} /\left(\mathrm{kg} \cdot{ }^{\circ} \mathrm{C}\right)\right]$, and $\rho_{1}$ is density of the workpiece material $\left(\mathrm{kg} / \mathrm{m}^{3}\right)$.

Suppose that $T_{0}$ is the initial temperature of workpiece, then the chip average temperature in the shear plane can be given by

$$
\bar{T}_{s}=T_{0}+\Delta T_{s}=T_{0}+\frac{R_{1} q_{1}}{c_{1} \rho_{1} v \sin \phi},
$$

where $\bar{T}_{s}$ is the average temperature in the shear plane. 
According to the computing method of average temperature caused by a moving dotted heat source in a semi-infinite object [8-11], the average temperature in the shear plane corresponding to the heat introduced into the workpiece can be obtained as follows:

$$
\bar{T}_{s}^{\prime}=T_{0}+0.754 \frac{\left(1-R_{1}\right) q_{1}}{\lambda_{1}} \sqrt{\frac{a_{1} a_{c} \cos \left(\phi-\gamma_{0}\right)}{v \sin \phi \cos \gamma_{0}}},
$$

where $\lambda_{1}$ is heat conductivity of the workpiece material at the average temperature for $\left(T_{0} \sim \bar{T}_{s}^{\prime}\right)\left[\mathrm{W} /\left(\mathrm{m} \cdot{ }^{\circ} \mathrm{C}\right)\right]$, and $a_{1}$ is thermal diffusivity of the workpiece material at temperature $\left(T_{0} \sim \bar{T}_{s}^{\prime}\right)\left(\mathrm{m}^{2} / \mathrm{s}\right)$.

A narrow shear plane can be considered as a face heat source, that is $\bar{T}_{s}=\bar{T}_{s}^{\prime}$. Also consider that thermal diffusivity $a_{1}=\lambda_{1} / c_{1} \rho_{1}$, while relative slippage of the shear plane $\varepsilon=\cos \gamma_{0} /\left(\sin \phi \cos \left(\phi-\gamma_{0}\right)\right)$. From Eqs. (3) and (4), the folowing relation can be obtained

$$
R_{1}=\frac{0.754 \sqrt{v a_{c} /\left(a_{1} \varepsilon\right)}}{1+0.754 \sqrt{v a_{c} /\left(a_{1} \varepsilon\right)}}=\frac{1}{1+1.3263 \sqrt{\frac{a_{1} \varepsilon}{v a_{c}}}} .
$$

Equation (5) shows that the ratio $\left(R_{1}\right)$ of heat distribution to chip increases with the increment of cutting speed $(v)$ or/and thickness $\left(a_{c}\right)$ of the cutting layer. It means that much more heat is carried away by chips, and less heat is conducted to the workpiece, especially in HSC. With reduction of thermal diffusivity $\left(a_{1}\right)$ and relative slippage $(\varepsilon)$, chips take more quantity of heat, which depends on the properties of the workpiece material. The experimental results prove that the removed chips take away a lot of heat at HSC, which leads to a low cutting temperature and reduction of thermal deformation effect on machining precision. Insofar as difficult-to-process materials have a low thermal diffusivity, and the cutting heat is not easy to be spread away, this results in a cutting temperature rise and intensifies the cutter wear and tear, thus shortening the cutter life. Therefore, in order to improve the processing quality and tool life in HSC, an appropriate choice of workpiece and cutter materials is necessary. In addition to this, reasonable cutting parameters are demanded. Numerous HSC tests for specific materials can be used for corroboration of the calculated results and further optimization. Obtaining the particular values of $R_{1}$ via experiments and substituting them into Eq. (4), one can acquire the average temperature $\left(\bar{T}_{S}\right)$ in the shear plane.

Average Temperature of Cutter Rake Face. A part of heat $\left(Q_{2}\right)$ produced by friction between the cutter and the chip flows into the chip and the other part - into the cutter. Assume that $R_{2}$ is the ratio of heat value corresponding to the chip, then the heat values related to the chip and the cutter are $R_{2} q_{2} l_{f} a_{w}$ and $\left(1-R_{2}\right) q_{2} l_{f} a_{w}$, respectively. In the course of cutting, the rub heat source of the cutter-to chip contact surface keeps moving along the cutter surface from the start to the end, while the chip runs off continuously. This is equivalent to a fixed heat source moving in an infinite plane. Then, the rise in the average temperature of the chip bottom face is

$$
\Delta \bar{T}_{f 1}=\frac{0.754 R_{2} q_{2}}{\rho_{2} c_{2}} \sqrt{\frac{l_{f} \xi}{a_{2} v}},
$$

where $\Delta \bar{T}_{f 1}$ is the average temperature rise $\left({ }^{\circ} \mathrm{C}\right), \rho_{2}$ is density of the workpiece material $\left(\mathrm{kg} / \mathrm{m}^{3}\right), c_{2}$ is specific heat value for the average temperature $\bar{T}_{s} \sim\left(\bar{T}_{s}+\bar{T}_{f}\right)\left[\mathrm{J} /\left(\mathrm{kg} \cdot{ }^{\circ} \mathrm{C}\right)\right]$, 
$a_{2}$ is thermal diffusivity of the workpiece material for temperature $\bar{T}_{s}+\bar{T}_{f}\left(\mathrm{~m}^{2} / \mathrm{s}\right)$, and $\xi$ is deformation coefficient. The average temperature in the chip rub area is

$$
\bar{T}_{f}=\bar{T}_{s}+\Delta \bar{T}_{f 1}=\bar{T}_{s}+\frac{0.754 R_{2} q_{2}}{\rho_{2} c_{2}} \sqrt{\frac{\xi l_{f}}{a_{2} v}} .
$$

With regard to the cutter, $\left(1-R_{2}\right) q_{2}$ refers to the fixed heat source, which implies the average temperature of the cutter rake face as follows:

$$
\bar{T}_{t}=\frac{\left(1-R_{2}\right) q_{2} l_{f}}{\lambda_{t}} \bar{A}_{t}+T_{0 t},
$$

where $\lambda_{t}$ is heat conductivity of the tool material at temperature of $\bar{T}_{t}\left[\mathrm{~W} /\left(\mathrm{m} \cdot{ }^{\circ} \mathrm{C}\right)\right], T_{0 t}$ is the initial temperature of the cutter $\left({ }^{\circ} \mathrm{C}\right)$, and $\bar{A}_{t}$ is coefficient of length-to width ratio related to the heat source area. Both $\bar{T}_{f}$ and $\bar{T}_{t}$ are the average temperatures of the cutter-to-chip contact area, which should be equal. In view of $v_{c}=v / \xi$, we obtain $R_{2}$ by combination of Eqs. (7) and (8)

$$
R_{2}=\frac{\frac{q_{2} l_{f} \bar{A}_{t}}{\lambda_{t}}+T_{0 t}-\bar{T}_{s}}{\frac{0.754 q_{2}}{\rho_{2} c_{2}} \sqrt{\frac{\xi l_{f}}{v a_{2}}}+\frac{q_{2} l_{f} \bar{A}_{t}}{\lambda_{t}}}=\frac{\frac{F_{f 1} v \bar{A}_{t}}{a_{w} \xi \lambda_{t}}+T_{0 t}-\bar{T}_{s}}{\frac{0.754 F_{f 1} v}{l_{f} a_{w} \xi c_{2} \rho_{2}} \sqrt{\frac{\xi l_{f}}{v a_{2}}}+\frac{F_{f 1} v \bar{A}_{t}}{a_{w} \xi \lambda_{t}}} .
$$

From formula (9), it can be seen that heat fluxes from the cutter-to-chip heat source to the chip are affected by many factors and are coupled with the heat flux from the shear plane to the chip. This coupling/interaction relates to the cutting speed and frictional conditions for the given cutting conditions. For the equal values of the tool and workpiece initial temperatures, Eq. (9) can be reduced to

$$
R_{2}=\frac{\bar{A}_{t} /\left(\xi \lambda_{t}\right)-\tau_{s} a_{w} \cos \gamma_{0} /\left[\left(1+1.3263 c_{1} \rho_{1} \sqrt{\left.a_{1} \varepsilon /\left(v a_{c}\right)\right)} \sin \phi \cos \left(\gamma_{0}-\phi\right) F_{f 1}\right]\right.}{0.754 /\left(c_{2} \rho_{2} \sqrt{v l_{f} \xi a_{2}}\right)+\bar{A}_{t} /\left(\xi \lambda_{t}\right)} .
$$

Equation (10) indicates that heat value related to a chip increases with cutting speed.

Average Temperature in the Machined Surface-Tool Flank Surface Contact Area. In the course of steady cutting, a part of heat is produced by sliding friction between the cutter flank surface and the workpiece machined surface, and it is distributed between the tool and the workpiece. Assume that the share/ratio of heat dissipated into the cutter is $R_{3}$, then the heat fluxes into the cutter and workpiece are $R_{3} q_{3}$ and $\left(1-R_{3}\right) q_{3}$, respectively. The rub heat source along the workpiece is a moving one. The temperature of the machined surface caused by heat dissipation $\left(1-R_{3}\right) q_{3}$ can be expressed as

$$
\bar{T}_{t w}=0.754 \frac{\left(1-R_{3}\right) q_{3} l_{w}}{\rho_{3} c_{3}} \sqrt{\frac{a_{3}}{v l_{w}}}+T_{0},
$$

where $a_{3}$ is thermal diffusivity of the workpiece material at temperature $\bar{T}_{t w}\left(\mathrm{~m}^{2} / \mathrm{s}\right), \rho_{3}$ is mass density of the workpiece material $\left(\mathrm{kg} / \mathrm{m}^{3}\right)$, and $c_{3}$ is specific heat of the workpiece material $\left[\mathrm{J} /\left(\mathrm{kg} \cdot{ }^{\circ} \mathrm{C}\right)\right]$. 
The rub heat source to the cutter flank surfac can be taken as a fixed heat source, as well. The average temperature of the contact area at the tool back surface is equal to

$$
\bar{T}_{w t}=\frac{R_{3} q_{3} l_{w}}{\lambda_{t}} \bar{A}_{w}+T_{0}
$$

where $\bar{\lambda}_{t}$ is heat conductivity of the workpiece material $\left[\mathrm{W} /\left(\mathrm{m} \cdot{ }^{\circ} \mathrm{C}\right)\right], \bar{A}_{w}$ is form factor related to the heat source size ratio $a_{w} / l_{w}$. Similarly to the cutter rake face, $R_{3}$ can be obtained from Eqs. (11) and (12) as

$$
R_{3}=\frac{\frac{0.754 q_{3} l_{w}}{\rho_{3} c_{3}} \sqrt{\frac{a_{3}}{v l_{w}}}}{\frac{0.754 q_{3} l_{w}}{\rho_{3} c_{3}} \sqrt{\frac{a_{3}}{v l_{w}}}+\frac{q_{3} l_{w}}{\lambda_{t}}}=\frac{1}{1+1.3263 \frac{\rho_{3} c_{3}}{\lambda_{t}} \sqrt{\frac{v l_{w}}{a_{3}}}} .
$$

From formula (13), it can be seen that the ratio of heat distribution for the tool manifests a significant reduction with cutting speed. After obtaining $R_{3}$ for the given cutting condition, it is easy to find the average temperature at the machined surface of the workpiece or at the cutter flank surface via Eq. (11) or Eq. (12).

Visualization of Heat Distribution. In order to derive the particular ratios of heat distribution between chip, workpiece and cutter in the cutting temperature fields for particular materials, caclulations were made for the cutting medium carbon steel and ceramic cutting tool, whose physical parameters are given Table 1 . The calculated heat distributions for the first and the third deformation zones are shown in Figs. 2 and 3, which illustrate the numerical expressions in Eqs. (5) and (13). It can be seen from Figs. 2 and 3 that the ratios of $R_{1}$ and $R_{3}$ vary with cutting speed.

$\mathrm{T}$ a $\mathrm{b} 1 \mathrm{e} 1$

Physical Parameters of Cutter and Workpiece Materials

\begin{tabular}{|c|c|c|}
\hline \multicolumn{2}{|c|}{ Materila } \\
\hline \multicolumn{2}{|c||}{ Workpiece } & Tool \\
\hline \multicolumn{2}{|c|}{ Medium carbon steel } & $\mathrm{Al}_{2} \mathrm{O}_{3}$ ceramic \\
\hline $\begin{array}{c}\text { Density } \\
\rho_{3}, \mathrm{~kg} / \mathrm{m}^{3}\end{array}$ & $\begin{array}{c}\text { Heat capacity } \\
\lambda_{3}, \mathrm{~J} /\left(\mathrm{kg} \cdot{ }^{\circ} \mathrm{C}\right)\end{array}$ & $\mathrm{W} /\left(\mathrm{kg} \cdot{ }^{\circ} \mathrm{C}\right)$ \\
\hline 7850 & 480 & 38.2 \\
\hline
\end{tabular}

Figure 2 shows that share of the energy consumed in shear deformation and dissipated in a chip (ratio Rl) increases with cutting speed. One can see that this ratio manifests a steep rise depicted by a straight line at low velocity, followed by less steep rise at the medium speed and saturation portion at high speed. Finally, it attains a constant value, which can be attributed to the fact that heat produced by shear deformation is carried away by rapidly flowing chips. As a consequence, less heat is dissipated in the workpiece. From Fig. 2, it can also be found that $96.24 \%$ of heat is carried away by the chip - at high speed. The simulated results imply that HSC is not only benefitial for the work efficiency but also makes it possible to reduce the cutting heat effect on the machining quality, which is confirmed by the available experimental results on the HSC. Thus, Fig. 2 can be used to design the cutting parameters for a workpiece with the required precision level and to 


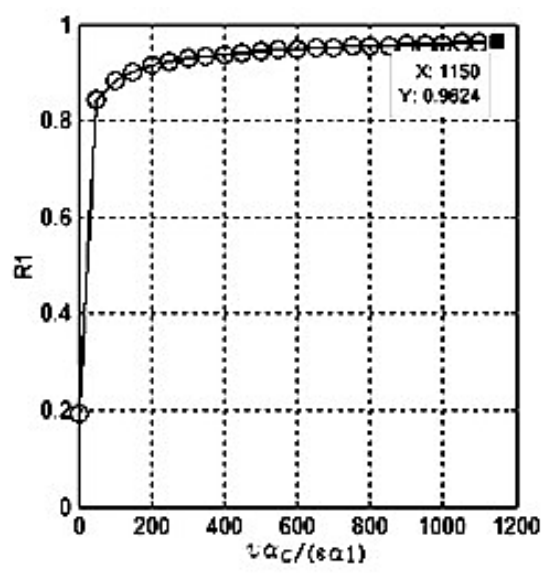

Fig. 2

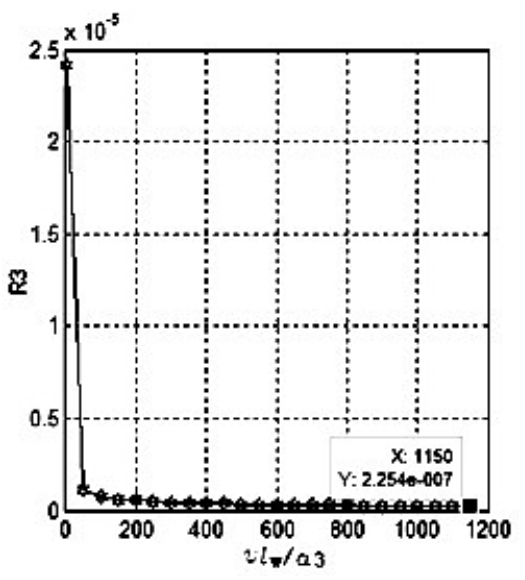

Fig. 3

Fig. 2. Rate of heat distribution in a chip for the first deformation zone.

Fig. 3. Rate of heat distribution in a cutter for the third deformation zone.

optimize the cutting conditions. For example, by determination of the cutting speed according to the accuracy requirements and heat transfer ratios, one can get robust evidence to establish the optimal HSC processing plans.

The heat distribution in the cutter depicted in Fig. 3 indicates that the heat ratio corresponding to the interface between a cutter and a machined surface is very small. This value is higher at low cutting speed for the given cutting conditions and is sharply reduced with cutting speed. This ratio in the third deformation zone (in the tool) is also very low, since under high-speed conditions there is not enough time for heat to dissipate into the tool, so the ratio $\left(R_{3}\right)$ of heat in the tool is very low. With increase in the cutting speed, time of heat conduction decreases sharply and it is too late for the rub heat to be transfered to the tool. The above statements show that wear and tear of the cutting tool flank surface is limited by the rub heat, which can supply a reference for research on tool wear mechanisms.

Conclusions. This paper ascertains heat sources of metal cutting by means of analysis of the energy consumption in three deformation zones for dry cutting. Models of heat generation are proposed and heat-conduction laws based on the energy from cutting deformation and frictional work at steady cutting. By using the average temperature computation of a moving heat source in a semi-infinite plane, one obtains the average temperatures in the shear plane and cutter rake face, with disregard of the cutter flank surface. This also provides distribution rates of the three heat sources for the chip, cutter and workpiece. Qualitative analysis for three deformation zones and quantitative visualization for heat distribution ratios of the first and third deformation zones have been validated by some experimental results.

1. The ratio of heat energy which is dissipated in a chip in the first deformation zone increases with cutting speed, increasing fastest at low speed, slower at intermediate speed, and then remains a constant value with the slowest increment at HSC. These results indicate that the HSC is advantageous to improve the processing efficiency and work accuracy.

2. The ratio of rub heat dissipated in a chip in the second deformation zone can increase with cutting speed, in which it reacts continuously with heat from the first deformation. Due to many complex influencing factors, this needs a further analytical investigation for the actual HSC conditions.

3. The ratio of rub heat dissipated in a tool in the third deformation is reduced with cutting speed, while this ratio descends fastest at low speed, slower at intermediate speed, 
and very slowly at high speed. For the given cutting conditions, $R_{3} \sim 1 \%$, which can offer a reference for studying the wear mechanism of flank surface of cutting tool at the HSC.

4. The acquired cutting-temperature-field model is applied to predict temperature of the shear plane, rake face and flank surface of a cutter and is instrumental for refining the HSC mechanism by the comparative analysis with the experimental results.

Acknowledgements. The support of this study by National Nature Science Foundation of China under Grant No. 51065014 and Postgraduate Tutors Scientific Research Project of Gan Su Province Education Department, China under Grant No. 1212-205 is greatly appreciated.

\section{Резюме}

Високошвидкісне різання широко використовується в авіакосмічній, автомобільній та інших галузях промисловості. Однак комплексний механізм процесу високошвидкісного різання ще недостатньо вивчений. На основі аналізу теплової рівноваги між тепловиділенням і споживанням енергії при високошвидкісній обробці без мастильно-охолоджуючої рідини запропоновано моделі теплових джерел та полів температур різання. Для аналізу впливу виділення і виходу тепла при обробці на високих швидкостях різання виведено математичні моделі температур різання для трьох зон деформування. Визначено співвідношення розподілу тепла між стружкою, різаком і заготівкою, що ілюструють ступінь пропорційності зі швидкістю за допомогою пакета прикладних програм MATLAB.

1. Y. C. Fu, High Effect Machining Technology for Difficult-to-Cut Materials [in Chinese], North-West Industry University Press, Xian (2010).

2. N. He, High Speed Cutting Technology [in Chinese], Press of Shanghai Science and Technology, Shanghai (2012).

3. R. Y. Chen, Metal Cutting Theory [in Chinese], China Machine Press, Beijing (1984).

4. H. P. An, Z. Y. Rui, and J. F. Guo, "Wear mechanism of coated tool during high speed machining," in: Proc. of Int. Conf. on Digital Manufacturing \& Automation (ICDMA) (2010), pp. 913-918.

5. H. P. An, Z. Y. Rui, and R. F. Wang, "A new method on choosing tool materials at high speed machining,” Adv. Mater. Res., 291-294, 745-749 (2011).

6. J. M. Longbottom and J. D. Lanham, "A review of research related to Salomon's hypothesis on cutting speeds and temperatures," Int. J. Mach. Tool. Manuf., 46, 1740-1747 (2006).

7. Z. Song and Y. B. Guo, "An experimental and analytical analysis on chip morphology, phase transformation, oxidation and their relations in finish hard milling," Int. J. Mach. Tool. Manuf., 49, 809-813 (2009).

8. H. P. An, D. F. Sheng, and G. Q. Yin, "The slip-line theory and its applications in the process of metal cutting," J. China Eng. Mach., 7, No. 3, 308-311 (2009).

9. Z. F. Liu, C. G. Zhang, and G. L. Ren, Dry Machining Technology and Application [in Chinese], China Machine Press (2005).

10. X. Ai, High Speed Cutting Technology [in Chinese], National Defense Industry Press, Beijing (2003).

11. J. C. Jaeger, "Moving Sources of Heat and the Temperature at Sliding Contacts," Proc. Roy. Soc. New South Wales, 76, 203-224 (1942). 